\title{
We-Think, We-Learn, We-Act: the Trialectic of Postdigital Collective Intelligence
}

\section{Petar Jandrić ${ }^{1}$}

Published online: 3 July 2019

(C) Springer Nature Switzerland AG 2019

According to the 2018 International Association of Scientific, Technical and Medical Publishers Report, the world now has between 7 and 8 million active researchers. 'There were about 33,100 active scholarly peer-reviewed English-language journals in mid-2018 (plus a further 9,400 non-English-language journals), collectively publishing over 3 million articles a year' (Johnson et al. 2018: 5). The number of scholarly articles grows at the rate of about $4 \%$ per year, and the number of scholarly journals grows at the rate of over 5\% per year (Johnson et al. 2018: 5). While these numbers significantly vary depending on competing definitions of researchers, scholarly journals, and articles, Postdigital Science and Education was definitely born into the age of plenty. However, abundance is not always positive. Staying up to date in many research areas has already become impossible because the number of newly published academic articles exceeds our ability to read them within a human lifetime (Peters et al. 2016). The most popular form of academic communication, scholarly article, is just one amongst 'around 100 different genres of writing' which academics write 'for a very wide range of different purposes' (Tusting et al. 2019: 65). In some fields, such as philosophy, the gold standard is still the academic monograph; other fields, such as education, experiment with new forms of publication such as video articles (see Video Journal of Education and Pedagogy 2019). So how do we find our way through this publication jungle? On our way into an age abundant with information, we have bumped into a serious knowledge problem.

In response, we develop various coping strategies. We reinvent new methods of searching-despite these efforts; too many articles resemble echo chambers which reflect the first five or ten pages of Google Scholar. We narrow down our research areas and close ourselves into communities and movements-members of postdigital science and education community tend to read (and cite) other members of postdigital science and education community, and members of critical pedagogy movement tend to read (and cite) other members of critical pedagogy movement. We reproduce age-old academic 'standards' which reinforce existing power relationships through academic

Petar Jandrić

pjandric@tvz.hr

1 Zagreb University of Applied Sciences, Zagreb, Croatia 
rentiership (Fuller 2019). We apply various computational methods (usually associated with artificial intelligences, deep learning, and such) to help us manage large amounts of information (usually in the form of big data). This puts us 'in the systems that are very gameable. (...) Yet, given that no-one has a better idea to how to coordinate knowledge on the scale of the moment, gamification of the knowledge apparatus is something to not entirely dismiss' (Wark in Jandrić 2017: 131). In our postdigital world, where digital technology and media is no longer 'separate, virtual, 'other' to a 'natural' human and social life' (Jandrić et al. 2018: 893), we have no other choice but develop new postdigital forms of collective intelligence.

Focusing on relationships between human beings and computers, Pierre Lévy defines collective intelligence as

a scientific, technical and political project that aims to make people smarter with computers, instead of trying to make computers smarter than people. So, collective intelligence is neither the opposite of collective stupidity nor the opposite of individual intelligence. It is the opposite of artificial intelligence. It is a way to grow a renewed human/cultural cognitive system by exploiting our increasing computing power and our ubiquitous memory. (in Peters 2015: 261)

Focusing to education, Siân Bayne develops the critical posthumanist approach 'where the social and the material worlds come together - where the human teacher's agency comes up against the workings of data to conduct another, and different, kind of teaching which is neither human not machinic but some kind of gathering of the two' (Bayne in Jandrić 2017: 206). However, this is easier said than done because of powerful constraints such as data bias (our data always reflect conditions of their collection) and algorithmic bias (the tendency of artificial intelligences to 'learn' and reproduce human biases) (see Jandrić 2019). At a small scale, we can try and avoid some of these biases using methods such as algorithm auditing (Hempel 2018). Looking more generally, however, our knowledge problem lies firmly in the context of cognitive bio-informational capitalism (Peters 2012).

Cognitive bio-informational capitalism prioritises epistemology over ontology; formalises, mathematicises, and aestheticises life experiences; centres production and accumulation on immaterial assets; extracts co-created and co-produced (symbolic) goods and experiences for the benefit of the few; pushes towards symbiosis of humans and machines; and much more (see Peters and Jandric 2018). In the age of cognitive bio-informational capitalism, we need a critical philosophy of the postdigital, which 'must be able to understand the processes of quantum computing, complexity science, and deep learning as they constitute the emerging techno-science global system and its place within a capitalist system that itself is transformed by these developments' (Peters and Besley 2019: 40). Situated within these circumstances, the challenge of postdigital collective intelligence can be summed up using three dialectically intertwined concepts: we-think, we-learn, and we-act. While this classification is by no means analytical, it does offer a productive lens for 'attacking' our knowledge problem here and now.

In our postdigital world we-think is not a coping strategy, a privilege, or even an option - it is our reality. Our information is mediated, our knowledge is co-constructed, and our instincts and methodologies stem from our personal and social histories. While it is tempting to see myself as a lone genius, like Hunter S. Thompson writing about 
fear and loathing in his hotel room in Las Vegas or like Charles Bukowski writing about his sexual encounters in a shabby motel, I am not alone in writing these words. This article owes a huge debt of gratitude to all people who passed through my life as a person and as a scholar (not that the two are exactly distinguishable). Recognising this debt of gratitude is not only about good manners; it is an epistemic necessity. The list of references at the bottom of this article, which indicates my intellectual ancestry, is just as important as the conclusions presented in this article. My thinking plays with thinking of my ancestors and my readers, and my article represents complex forces shaping my life including, but far from limited to, my editorial responsibility in Postdigital Science and Education. And this responsibility is at least twofold: we need to understand the epistemic consequences of our we-think, and we need to develop new strategies for we-thinking in and for the future.

We-think arrives into being through we-learn, and we-learn is an essential attribute of human beings. Schooling, which is too often deemed synonymous with learning, is just a small part of this process.

Babies learn to speak without going to baby speaking school, babies learn to walk without going to baby walking school. Of course, people pick up skills from their environments, it is not as if they live in a vacuum, but just by being in the world, by being human, we have a natural drive towards those actions. (Taylor in Jandrić 2017: 226).

Digital technologies have brought about new opportunities for we-learn, which, after a couple of decades of excitement with novelty, have now entered mainstream (see Cormier et al. 2019) — and far too often in terms of neoliberal framings such as lifelong learning (Knox 2016). According to Fawns, 'ideas like "digital education" are useful insofar as they encourage people to look closer at what is happening but become problematic when used to close down ideas or attribute instrumental or essential properties to technology' (Fawns 2019: 142). In this context, 'the postdigital might be understood as a kind of "holding to account" of many of the assumptions associated with digital technologies in education' (Knox 2019). Postdigital we-learn is not only about the digital, or the analogue, or the human, or the technological - it recognises that 'we need to be open to the cross-fertilisation process', and insists that we should 'not allow it to become cross-sterilisation' (Sinclair and Hayes 2019: 130).

We-act closes the trialectic with we-think and we-learn as a foundational necessity, as a precondition, as a consequence, and as everything in the between. Frankfurt School theorists, postcolonial thinkers, members of the critical pedagogy movement, and many others, have captured a part of this relationship in the concept of praxis - and this concept has served us well in many social, political, and epistemic struggles over the years. In our postdigital age, however, we-act requires 'a move away from the ironic distantiation and self-indulgent detachment of the vulgar divas of the academy who clearly chose identity politics over class politics (and in so doing became complicitous in the very relations of inequality they officially rejected)' (McLaren and Jandric forthcoming). Right now we are playing the game of identity politics very well; not the least because such politics does nothing to challenge (cognitive bio-informational) capitalism. However, postdigital we-act cannot remain complicit with our current social order. It requires us to form 'coalitions and united fronts in political and social 
struggles' (Ford 2019: 116); in a university context, it requires us to face the 'triple challenge of social division, multiple discourses and an impaired democracy' (Barnett 2019). We-act speaks about the interplay of our postdigital work 'in, against and beyond' (Holloway 2016) cognitive bio-informational capitalism and urges us to take individual and group responsibility for own actions.

We-think, we-learn, and we-act have always been the basic building blocks of the human condition. 'Both a rupture in our existing theories and their continuation' (Jandrić et al. 2018: 895), the postdigital context has somewhat transformed these concepts and created a new dynamic between them. Some articles in this issue of Postdigital Science and Education focus to we-think, others say more about we-learn, and the growing number of practice-oriented and collectively written articles indicates authors' need to engage with we-act. To each their own; after a careful review process, I can testify that each and every article offers a lot of value to our understanding of postdigital science and education. In this Editorial, I merely wanted to remind myself and others of deep relationships between we-think, we-learn, and we-act. This relationship can be best described by a dialectics of triplicity or a trialectic (Soja 1996). Any thinking, individual or collective, is derived from and produces learning. Any thinking and learning might have been derived from the actions of someone or something else or might provoke new thinking, learning, or action, by someone or something else. Whatever our research focus, question, or goal, the trialectic of postdigital collective intelligence is here to stay. We need to be aware of the trialectic between we-think, we-learn, and we-act and make the most of this trialectic, in our research endeavours to come.

\section{References}

Barnett, R. (2019). University challenge: division, discourse and democracy. Postdigital Science and Education. https://doi.org/10.1007/s42438-019-00044-z.

Cormier, D., Jandrić, P., Childs, M., Hall, R., White, D., Phipps, L., Truelove, I., Hayes, S., \& Fawns, T. (2019). Ten years of the postdigital in the 52 group: reflections and developments 2009-2019. Postdigital Science and Education. https://doi.org/10.1007/s42438-019-00049-8.

Fawns, T. (2019). Postdigital education in design and practice. Postdigital Science and Education, 1(1), 132145. https://doi.org/10.1007/s42438-018-0021-8.

Ford, D. R. (2019). Pedagogy of the "Not": negation, exodus, and postdigital temporal regimes. Postdigital Science and Education, 1(1), 104-118. https://doi.org/10.1007/s42438-018-0009-4.

Fuller, S. (2019). Against academic rentiership: a radical critique of the knowledge economy. Postdigital Science and Education. https://doi.org/10.1007/s42438-019-00035-0.

Hempel, J. (2018). Want to prove your business is fair? Audit your algorithm. Wired, 5 September. https:/www.wired.com/story/want-to-prove-your-business-is-fair-audit-your-algorithm/. Accessed 17 June 2019.

Holloway, J. (2016). In, against, and beyond capitalism: the San Francisco lectures. Oakland: PM Press/ Kairos.

Jandrić, P. (2017). Learning in the age of digital reason. Rotterdam: Sense.

Jandrić, P. (2019). The postdigital challenge of critical media literacy. The International Journal of Critical Media Literacy, 1(1), 26-37. https://doi.org/10.1163/25900110-00101002.

Jandrić, P., Knox, J., Besley, T., Ryberg, T., Suoranta, J., \& Hayes, S. (2018). Postdigital science and education. Educational Philosophy and Theory, 50(10), 893-899. https://doi.org/10.1080 /00131857.2018.1454000. 
Johnson, R., Watkinson, A., \& Mabe, M. (2018). The STM report: an overview of scientific and scholarly publishing. The Hague: International Association of Scientific, Technical and Medical Publishers https://www.stm-assoc.org/2018_10_04_STM_Report_2018.pdf. Accessed 17 June 2019.

Knox, J. (2016). Posthumanism and the massive open online course: contaminating the subject of global education. New York: Routledge.

Knox, J. (2019). What does the 'postdigital' mean for education? Three critical perspectives on the digital, with implications for educational research and practice. Postdigital Science and Education. https://doi. org/10.1007/s42438-019-00045-y.

McLaren, P., \& Jandrić, P. (forthcoming). Postdigital correspondences: cross border reflections on critical pedagogy, liberation theology and information technology. London: Bloomsbury.

Peters, M. A. (2012). Bio-informational capitalism. Thesis Eleven, 110(1), 98-111. https://doi.org/10.1177 $/ 0725513612444562$.

Peters, M. A. (2015). Interview with Pierre A. Lévy, French philosopher of collective intelligence. Open Review of Educational Research, 2(1), 259-266. https://doi.org/10.1080/23265507.2015.1084477.

Peters, M. A., \& Besley, T. (2019). Critical philosophy of the postdigital. Postdigital Science and Education, 1(1), 29-42. https://doi.org/10.1007/s42438-018-0004-9.

Peters, M. A., \& Jandrić, P. (2018). The Digital University: a dialogue and manifesto. New York: Peter Lang.

Peters, M. A., Jandrić, P., Irwin, R., Locke, K., Devine, N., Heraud, R., Gibbons, A., Besley, T., White, J., Forster, D., Jackson, L., Grierson, E., Mika, C., Stewart, G., Tesar, M., Brighouse, S., Arndt, S., Lazariou, G., Mihalia, R., Bernade, L., Legg, C., Ozolins, J., \& Roberts, P. (2016). Toward a philosophy of academic publishing. Educational Philosophy and Theory, 48(14), 1401-1425. https://doi.org/10.1080 /00131857.2016.1240987.

Sinclair, C., \& Hayes, S. (2019). Between the post and the com-post: examining the postdigital 'work' of a prefix. Postdigital Science and Education, 1(1), 119-131. https://doi.org/10.1007/s42438-018-0017-4.

Soja, E. W. (1996). Thirdspace: Journeys to Los Angeles and other real-and-imagined places. Oxford: WileyBlackwell.

Tusting, K., McCulloch, S., Bhatt, I., Hamilton, M., \& Barton, D. (Eds.). (2019). Academics writing: the dynamics of knowledge creation. London and New York: Routledge.

Video Journal of Education and Pedagogy (2019). About. https://brill.com/view/journals/vjep/vjep-overview. $\mathrm{xml}$ ?rskey $=\mathrm{zhCa} 68 \&$ result $=1$. Accessed 17 June 2019. 